\title{
High-Temperature Oxidation Behavior of Elemental Powder Metallurgy Processed TiAl-Mn-Mo-C Alloys with Yttrium Addition
}

\author{
Ying $\mathrm{Wu}^{1,2, *}$, Sun Keun Hwang ${ }^{1}$ and Yukichi Umakoshi ${ }^{2}$ \\ ${ }^{1}$ School of Materials Science and Engineering, Inha University, Incheon 402-751, Korea \\ ${ }^{2}$ Department of Materials Science and Engineering, Graduate School of Engineering, Osaka University, Suita 565-0871, Japan
}

Effects of yttrium addition on the formation of oxide scales and the oxidation resistance of elemental powder metallurgy (EPM) processed TiAl-Mn-Mo-C alloys were studied. The Y-containing TiAl-based alloys $(0.1 \sim 0.6$ at $\%$ Y) showed better oxidation resistance than Y-free alloy oxidized in air at $800^{\circ} \mathrm{C}$ for $350 \mathrm{~h}$. The Y-containing alloys showed a significantly reduced weight gain, especially for 0.6 at $\% \mathrm{Y}$-added alloy. In the $\mathrm{Y}$-free alloy, the scale formed during extended air-exposure at $800^{\circ} \mathrm{C}$ consisted of $\mathrm{TiO}_{2}$ and $\alpha-\mathrm{Al}_{2} \mathrm{O}_{3}$. For 0.6 at $\% \mathrm{Y}$-added alloy, however, the oxide scale was composed of a complex mixture of $\mathrm{TiO}_{2}, \alpha-\mathrm{Al}_{2} \mathrm{O}_{3}, \mathrm{Y}_{2} \mathrm{O}_{3}$ and $\mathrm{Al}_{5} \mathrm{Y}_{3} \mathrm{O}_{12}$. The formation of multi-phase (Y, Al)O-type oxides layer in a transitional Y-rich subscale close to the substrate and an increase of the amount of $\alpha-\mathrm{Al}_{2} \mathrm{O}_{3}$ in the mixture oxide layer in the $\mathrm{Y}$-added alloys were the main contributor to improving the oxidation resistance of the alloys. The reduction of oxygen content in the substrate also had a beneficial effect on the oxidation resistance of the Y-containing TiAl-based alloys.

(Received December 3, 2003; Accepted February 19, 2004)

Keywords: titanium aluminides, oxidation, oxides, structure, yttrium

\section{Introduction}

Structural materials used for advanced aircraft engines and gas turbine blades at high temperature are required to show good oxidation resistance. The performance of TiAl-based alloys as new structural materials depends strongly on their oxidation resistance. ${ }^{1)}$ Inadequate oxidation resistance limits the use of current TiAl-based alloys above about $800^{\circ} \mathrm{C}$, however, because the external layer formed on the substrates is not a protective $\mathrm{Al}_{2} \mathrm{O}_{3}$ scale, but a $\mathrm{TiO}_{2}$ scale or a mixture of these two oxides. ${ }^{2)}$ Some of the methods are developed to improve the oxidation resistance of TiAl alloys: alloying by adding ternary and quaternary elements, ${ }^{3-8)}$ surface coating ${ }^{9,10)}$ and ion implantation of alloy elements. ${ }^{11,12)}$ In the case of alloying, a strong resistance to the oxidation of TiAlbased alloys is sought by forming a protective $\mathrm{Al}_{2} \mathrm{O}_{3}$ layer or a new barrier layer that can block diffusion of titanium ions on the oxide interface, thereby preventing the rapid growth of $\mathrm{TiO}_{2}$ scale. Although a great deal of research has already been reported to improve the oxidation resistance by alloying elements such as $\mathrm{Nb}, \mathrm{Mo}, \mathrm{Si}, \mathrm{Ta}, \mathrm{Sb}, \mathrm{Ag}, \mathrm{W}, \mathrm{Cl}, \mathrm{F}, \mathrm{P}$ and others, it should be mentioned that some elements which improve oxidation resistance in many cases have a negative effect on the mechanical properties..$^{3-8,13-18)}$ In our previous studies, it has been found that yttrium is a good alloying element to improve the mechanical properties and oxidation resistance without sacrificing the ductility of TiAl-based alloys. ${ }^{19,20)}$ Also several investigators have studied the effect of yttrium addition as a metallic constituent, and the high temperature oxidation behavior of alloy systems other than $\mathrm{TiAl}^{21-25)}$ and have found that yttrium addition is beneficial. Therefore, yttrium is an attractive element with which to study the oxidation resistance of TiAl-based alloys.

The aim of this paper was to determine the oxidation behavior of elemental powder metallurgy (EPM) processed TiAl-Mn-Mo-C alloys containing various amounts of yttrium $(0.1 \sim 0.6$ at $\%)$, focusing on the oxidation kinetic as well as the composition and microstructural evolution of oxide scales.

\section{Experimental}

Oxidation tests were conducted on four TiAl-based alloys. Table 1 shows the chemical compositions of these alloys in which the yttrium content was changed from 0 to 0.6 at $\%$ while the contents of the alloying elements of Mn, Mo and C remain constant. The present materials were fabricated by EPM, the processing details of which are described elsewhere. $^{26-29)}$ Prior to the oxidation tests, the extruded rods were heat treated in an argon atmosphere. The heat treatment

Table 1 Chemical composition of the experimental alloys.

\begin{tabular}{|c|c|c|c|c|c|c|}
\hline \multirow{2}{*}{ Nominal } & \multicolumn{6}{|c|}{ Analysis (at\%) } \\
\hline & $\mathrm{Ti}$ & $\mathrm{Al}$ & $\mathrm{Mn}$ & Mo & $\mathrm{C}$ & $\mathrm{Y}$ \\
\hline Ti-46.6Al-1.4Mn-2Mo-0.3C & 50.18 & 46.21 & 1.32 & 1.98 & 0.31 & - \\
\hline Ti-46.6Al-1.4Mn-2Mo-0.3C-0.10Y & 49.99 & 46.30 & 1.31 & 2.01 & 0.30 & 0.09 \\
\hline Ti-46.6Al-1.4Mn-2Mo-0.3C-0.33Y & 50.56 & 45.56 & 1.29 & 2.02 & 0.29 & 0.28 \\
\hline $\mathrm{Ti}-46.6 \mathrm{Al}-1.4 \mathrm{Mn}-2 \mathrm{Mo}-0.3 \mathrm{C}-0.60 \mathrm{Y}$ & 49.32 & 46.48 & 1.30 & 2.06 & 0.29 & 0.55 \\
\hline
\end{tabular}

*The average concentration of oxygen in the samples was approximately $1500 \mathrm{ppm}$ regardless of the compositions. 

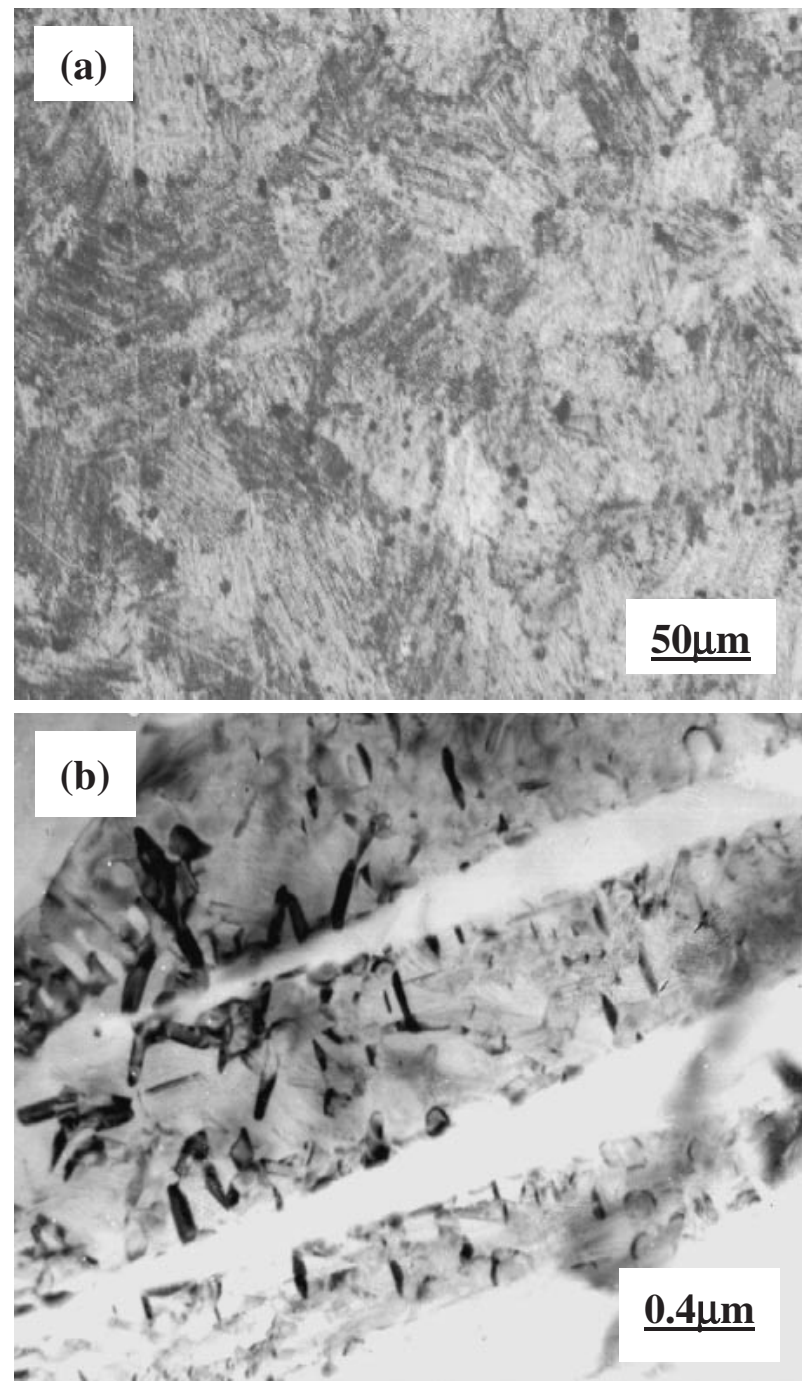

Fig. 1 Micrographs showing (a) fully lamellar microstructure of aligned $\alpha_{2}+\gamma$ platelets and (b) $\mathrm{Y}_{2} \mathrm{O}_{3}$ particles formed in $\gamma$ platelets in EPM Ti46.6Al-1.4Mn-2Mo-0.3C-0.33Y alloy heat treated at $1400^{\circ} \mathrm{C} / 1 \mathrm{~h} / \mathrm{AC}+$ $800^{\circ} \mathrm{C} / 12 \mathrm{~h} / \mathrm{AC}$.

cycles consisted of a solution treatment at $1400^{\circ} \mathrm{C}$ for $1 \mathrm{~h}$ followed by air cooling (AC) and an aging treatment at $800^{\circ} \mathrm{C}$ for $12 \mathrm{~h}$. Microstructural analysis of the specimens was performed by optical microscopy and an $\mathrm{H}-800$ transmission electron microscope operated at $200 \mathrm{kV}$. Metallographic examinations revealed that microstructures consisted predominantly of full lamellae of aligned $\alpha_{2}+\gamma$ platelets and minor amounts of oxide precipitates of $\mathrm{Y}_{2} \mathrm{O}_{3}$ particles, in $\gamma$ platelets as shown in Figs. 1 (a) and (b), respectively. The presence of $\mathrm{Y}_{2} \mathrm{O}_{3}$ precipitates in the alloys with higher content of yttrium was also evidenced by the results of $\mathrm{X}$-ray diffractometry (XRD) as shown in Fig. 2. The peak of $\mathrm{Y}_{2} \mathrm{O}_{3}$ in $(222)$ at $2 \theta=29.2^{\circ}$ was detected in 0.6 at $\%$ Y-added alloy (Fig. 2(b)). As reported previously, ${ }^{19)}$ the concentration of internal oxygen of the EPM TiAl alloys was reduced by additions of yttrium and the oxides of $\mathrm{Y}_{2} \mathrm{O}_{3}$ precipitated by the reaction of yttrium with the internal oxygen which was introduced during EPM processing of the experimental alloys. Because there is strong binding between yttrium and oxygen atoms, ${ }^{30)}$ and because the average oxygen concentration of EPM experimental alloys is 1500 mass ppm, which

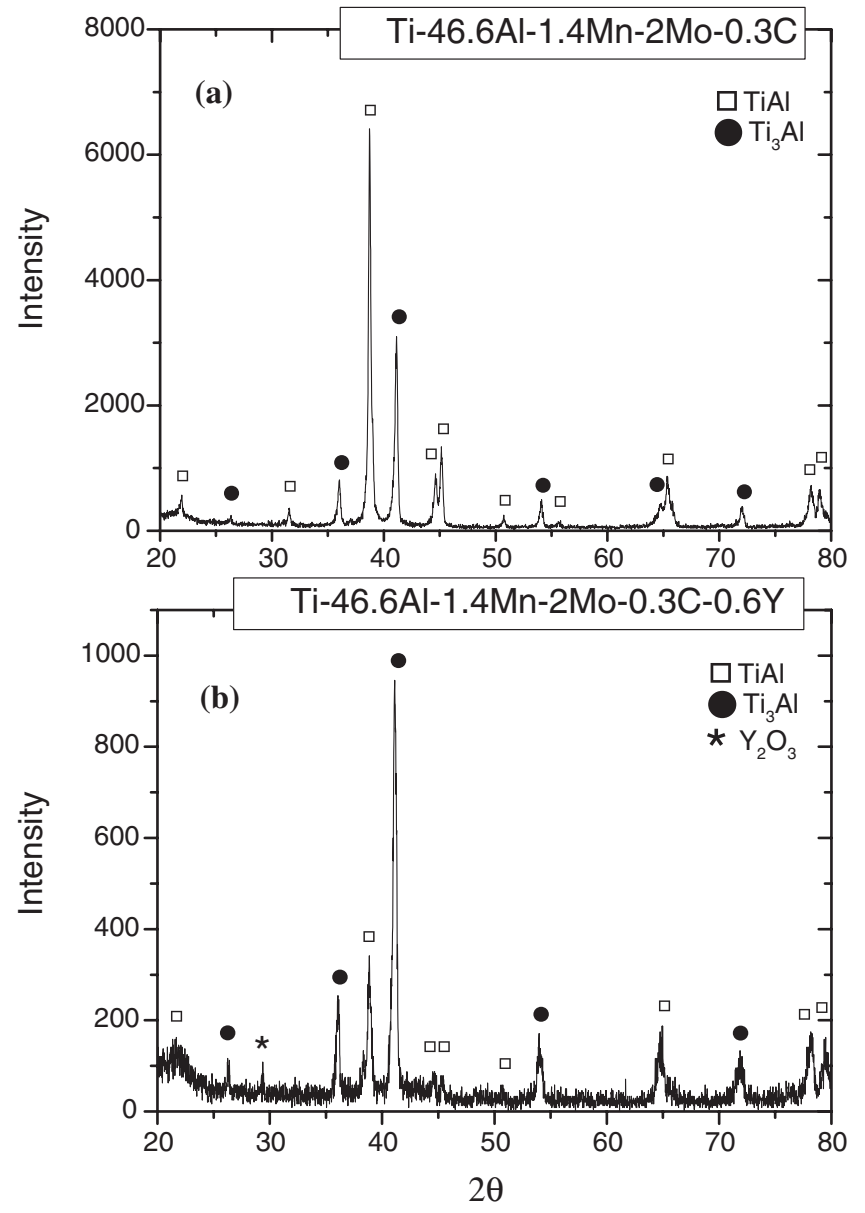

Fig. 2 XRD diffraction spectra of Ti-46.6Al-1.4Mn-2Mo-0.3C alloy prior to oxidation: (a) Y-free and (b) 0.6 at $\%$ Y-added alloys.

is about ten times higher than the solubility limit of 128 mass $\mathrm{ppm},{ }^{31)}$ supersaturated oxygen is prone to react with yttrium to form the $\mathrm{Y}_{2} \mathrm{O}_{3}$ particles.

Specimens $\left(5 \times 9 \times 2 \mathrm{~mm}^{3}\right)$ were cut from rod materials, polished with emery papers of up to 1200 mesh finish and ultrasonically cleaned for an additional $15 \mathrm{~min}$ in ethanol. Isothermal oxidation tests of the specimens were conducted using a thermo-balance in laboratory air at $800^{\circ} \mathrm{C}$ for up to $350 \mathrm{~h}$. After these tests, the oxidation products formed were examined by XRD using $\mathrm{Cu}\left(\mathrm{K}_{\alpha}\right)$ target. Surface and crosssectional morphologies of the oxides were observed by a scanning electron microscope (SEM). Distributions of elements in the cross-section of the oxides were analyzed by energy-dispersive X-ray spectrometry (EDS) in SEM and also by an electron probe micro-analyzer (EPMA).

\section{Results}

\subsection{Isothermal oxidation kinetics}

Figure 3 shows the mass gain per unit surface area of TiAlbased alloys oxidized in laboratory air as a function of exposure time at $800^{\circ} \mathrm{C}$. The mass gain apparently decreased with increasing yttrium content. The mass gain of 0.6 at $\%$ Yadded alloy was approximately $1 / 3$ that of Y-free alloy and Ti-50Al alloy ${ }^{32)}$ after $350 \mathrm{~h}$ exposure. All of the oxidation kinetic curves consisted of two stages: a linear and a 


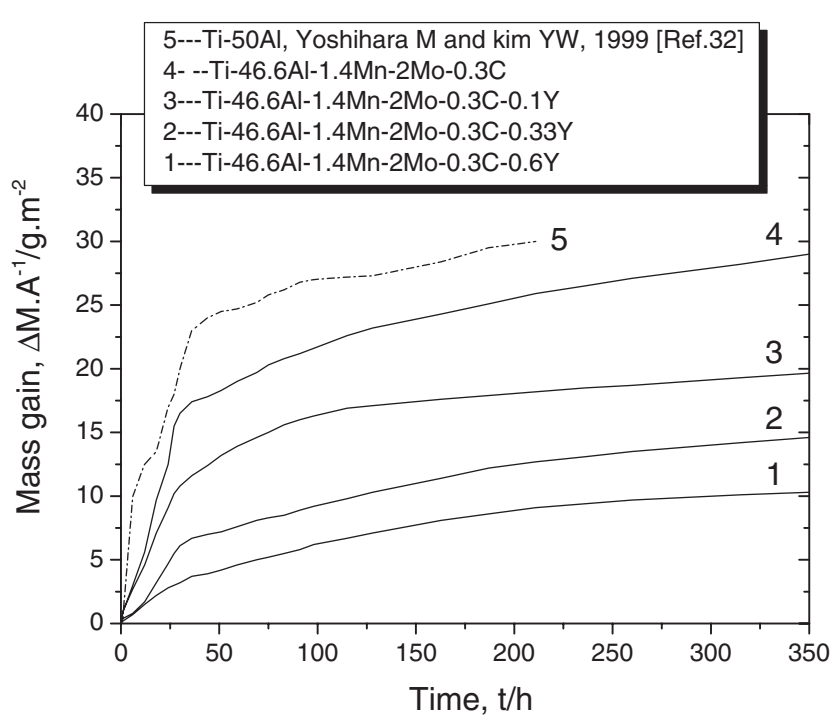

Fig. 3 Effect of yttrium on the oxidation kinetics of EPM Ti-46.6Al$1.4 \mathrm{Mn}-2 \mathrm{Mo}-0.3 \mathrm{C}-x \mathrm{Y}$ alloys in air at $800^{\circ} \mathrm{C}$. Samples were heat treated at $1400^{\circ} \mathrm{C} / 1 \mathrm{~h} / \mathrm{AC}+800^{\circ} \mathrm{C} / 12 \mathrm{~h} / \mathrm{AC}$. Refer to Table 2 for the quantitative kinetics data.

parabolic stage. Results of the isothermal oxidation tests are summarized in Table 2, in which the parabolic rate constant, $K_{\mathrm{p}}$, from the second stage of the oxidation curves, the mass gain and the thickness of oxide scale for each alloy after $350 \mathrm{~h}$ exposure at $800^{\circ} \mathrm{C}$ are found to be closely related to the yttrium content. In addition to the oxidation rate, the values of $K_{\mathrm{p}}$ and thickness of the oxide scale became smaller as the quantity of yttrium added was increased. Under these oxidation conditions, the addition of yttrium significantly improved the oxidation resistance of TiAl-Mn-Mo-C alloys.

\subsection{Composition and surface morphology of oxide scale}

Through analysis of the phases in scales by XRD, a difference between the Y-free alloy and Y-containing alloys was identified as shown in Table 2. Figure 4 shows the XRD diffraction spectra of the oxide scales formed in TiAl-based alloys exposed at $800^{\circ} \mathrm{C}$ for $350 \mathrm{~h}$. Basically four different oxide phases were distinguishable, $\mathrm{TiO}_{2}$ (rutile), $\alpha-\mathrm{Al}_{2} \mathrm{O}_{3}$, $\mathrm{Y}_{2} \mathrm{O}_{3}$ and $\mathrm{Al}_{5} \mathrm{Y}_{3} \mathrm{O}_{12}$. The XRD diffraction spectra obtained from Y-free TiAl alloy (Fig. 4(a)) and 0.1 at\% Y-added alloy (Fig. 4(b)) after longer exposure time only contain peaks from the mixture of the $\mathrm{TiO}_{2}$ and $\alpha-\mathrm{Al}_{2} \mathrm{O}_{3}$ phases. However, the oxide scales in 0.33 at $\% \mathrm{Y}$-added and 0.6 at $\% \mathrm{Y}$-added alloy were significantly thinner than those of the former alloys from the SEM observation. Moreover the scales consisted of all four oxide phases as shown in Figs. 4(c) and (d), although the amounts of $\mathrm{Y}_{2} \mathrm{O}_{3}$ and $\mathrm{Al}_{5} \mathrm{Y}_{3} \mathrm{O}_{12}$ phases were slightly higher in the 0.6 at $\%$ Y-added alloy.

Figure 5 shows the XRD diffraction spectra at the incident beam angle of $1^{\circ}$ of the oxide scales formed in Y-free TiAl alloy at $800^{\circ} \mathrm{C}$ after various periods of isothermal exposure. After $1 \mathrm{~h}$ oxidation at $800^{\circ} \mathrm{C}$ (Fig. 5(a)) a thin oxide scale was found to be a mixture of $\mathrm{TiO}_{2}$ and $\alpha-\mathrm{Al}_{2} \mathrm{O}_{3}$. Some peaks of TiAl from the underlying material were also determined. With increasing oxidation time up to $48 \mathrm{~h}$ (Fig. 5(b)) and $100 \mathrm{~h}$ (Fig. 5(c)), the oxide scales grew thicker but no crystallographic phase change occurred except for change in the relative peak heights of $\mathrm{TiO}_{2}$ and $\alpha-\mathrm{Al}_{2} \mathrm{O}_{3}$.

The appearance of $\mathrm{Y}_{2} \mathrm{O}_{3}$ and $\mathrm{Al}_{5} \mathrm{Y}_{3} \mathrm{O}_{12}$ phases in the alloy containing 0.33 at $\% \mathrm{Y}$ or 0.6 at $\% \mathrm{Y}$ was detected only after an extended exposure at high temperature. The progress of oxidation with exposure time of the 0.33 at $\%$ Y-added alloy is illustrated in Fig. 6. At oxidation for $1 \mathrm{~h}$, only $\mathrm{TiO}_{2}$ and $\alpha$ $\mathrm{Al}_{2} \mathrm{O}_{3}$ phases appeared. Due to the minimal thickness of the oxide scale, the substrate TiAl phase was also detectable in the XRD spectrum. Formation of $\mathrm{Y}_{2} \mathrm{O}_{3}$ and $\mathrm{Al}_{5} \mathrm{Y}_{3} \mathrm{O}_{12}$ phases was noticed after exposures for $48 \mathrm{~h}$ and $100 \mathrm{~h}$, respectively, so that all four phases were present thereafter.

SEM examination of the oxidation process of the TiAlbased alloys revealed an interesting development of morphological features and variation in chemical composition of the oxide scales that is consistent with the XRD result of Fig. 4. The oxide scales of all the specimens at $800^{\circ} \mathrm{C}$ after $350 \mathrm{~h}$ isothermal exposure showed a common feature of granular oxide particles. However, the Y-containing alloys $(0.33$ at $\% \mathrm{Y}$ or 0.6 at $\% \mathrm{Y})$ were associated with a greater amount of aluminum and yttrium in the oxide scales compared to the Y-free or Y-lean $(0.1$ at $\%$ Y) alloys.

In accord with the XRD analysis results of Y-free alloy in Fig. 5, the surface microstructural evolution as a function of oxidation time under SEM observation showed that the oxide layer consisted of granular phases, and the average size of individual grains varied from $0.5 \mu \mathrm{m}$ to about $5 \mu \mathrm{m}$ with exposure time of $1 \mathrm{~h}$ and $350 \mathrm{~h}$, respectively. With increasing oxidation time, the number of coarse-grained oxides increased on the scales of the surface. The oxide scale was enriched only with $\mathrm{Ti}$ and oxygen at all the periods of exposure. Especially to be noted was that the spallation problem occurred in the Y-free alloy after oxidation at $800^{\circ} \mathrm{C}$ for $350 \mathrm{~h}$.

Figure 7 shows SEM micrographs of the surface morphology of Ti-46.6Al-1.4Mn-2Mo-0.3C-0.6Y alloy oxidized isothermally at $800^{\circ} \mathrm{C}$ for different exposure times of 1 to

Table 2 Results of isothermal oxidation of the experimental alloys at $800^{\circ} \mathrm{C}$ for $350 \mathrm{~h}$.

\begin{tabular}{cccc}
\hline Alloy & $\begin{array}{c}K_{\mathrm{p}} \\
\left(\mathrm{g}^{2} \cdot \mathrm{m}^{-4} \mathrm{~h}^{-1}\right)\end{array}$ & $\begin{array}{c}\text { Mass gain } \\
\left(\mathrm{g} \cdot \mathrm{m}^{-2}\right)\end{array}$ & \multicolumn{2}{c}{ Scale thickness } \\
$(\mu \mathrm{m})$ & 29.12 & $24-30$ \\
\hline $\mathrm{Ti}-46.6 \mathrm{Al}-1.4 \mathrm{Mn}-2 \mathrm{Mo}-0.3 \mathrm{C}$ & 2.4 & 19.65 & $20-25$ \\
\hline $\mathrm{Ti}-46.6 \mathrm{Al}-1.4 \mathrm{Mn}-2 \mathrm{Mo}-0.3 \mathrm{C}-0.1 \mathrm{Y}$ & 1.1 & 14.61 & $\mathrm{TiO}_{2}, \mathrm{Al}_{2} \mathrm{O}_{3}$ \\
\hline $\mathrm{Ti}-46.6 \mathrm{Al}-1.4 \mathrm{Mn}-2 \mathrm{Mo}-0.3 \mathrm{C}-0.33 \mathrm{Y}$ & 0.6 & $\mathrm{TiO}_{2}, \mathrm{Al}_{2} \mathrm{O}_{3}, \mathrm{Y}_{2} \mathrm{O}_{3}$, & $\mathrm{Al}_{5} \mathrm{Y}_{3} \mathrm{O}_{12}$ \\
\hline $\mathrm{Ti}-46.6 \mathrm{Al}-1.4 \mathrm{Mn}-2 \mathrm{Mo}-0.3 \mathrm{C}-0.6 \mathrm{Y}$ & 0.3 & 10.30 & $10-15$ \\
\hline
\end{tabular}



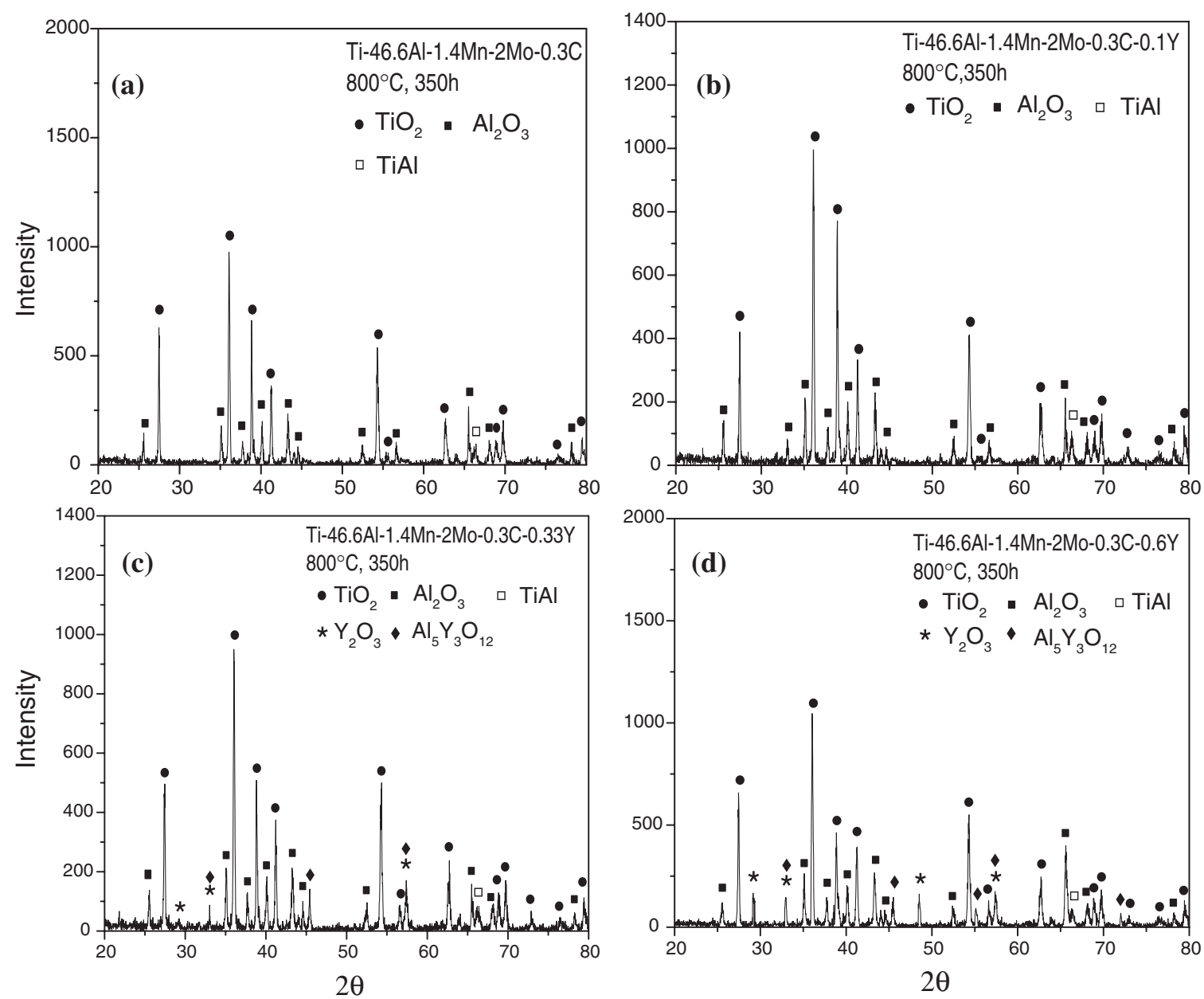

Fig. 4 XRD diffraction spectra of the oxide scales formed at $800^{\circ} \mathrm{C}$ after $350 \mathrm{~h}$ isothermal exposure in EPM Ti-46.6Al-1.4Mn-2Mo-0.3C alloy: (a) Y-free, and alloys containing (b) 0.1 at $\% \mathrm{Y}$, (c) 0.33 at $\% \mathrm{Y}$ and (d) 0.6 at $\%$.

$100 \mathrm{~h}$. No spallation of oxide particles was observed after cooling. The size of oxide crystals increased gradually with exposure time. EDS results indicated that the outer part of the oxide scale, formed after $1 \mathrm{~h}$ (Fig. 7(a)) at $800^{\circ} \mathrm{C}$ was composed mainly of titanium and oxygen. Aluminum in the oxide layer was slightly detected after $1 \mathrm{~h}$ exposure but was unmistakably identified after $48 \mathrm{~h}$ of oxidation. After $48 \mathrm{~h}$ (Fig. 7(b)) of isothermal oxidation the surface of the alloy was covered with oxide particles enriched with titanium and aluminum. The intensity of yttrium was weak at $48 \mathrm{~h}$ of exposure but was clearly evident after $100 \mathrm{~h}$ of oxidation. After $100 \mathrm{~h}$ exposure, the overall scale was enriched with a large number of oxide particles of titanium, aluminum or yttrium. However, the oxides in Fig. 7(c) showed a pillar-like feature, indicating the formation of $\mathrm{TiO}_{2}$ crystal in the outmost layer.

\subsection{Cross-sectional microstructures}

Figure 8 shows typical micrographs of a cross-section through part of the scale formed on Ti-46.6Al-1.4Mn-2Mo$0.3 \mathrm{C}$ alloy for different isothermal exposure times at $800^{\circ} \mathrm{C}$. The EDS results in Table 3 show that the structure of the scales is relatively simple and consists in the order of Mo-rich $\mathrm{Ti}_{3} \mathrm{Al}$ layer (II)/Mixed layer (III) $/ \mathrm{TiO}_{2}$ crystal (V) from the inside. With increase in the exposure time from $48 \mathrm{~h}$ (Fig. 8(a)) to $350 \mathrm{~h}$ (Fig. 8(b)), the thickness of oxide scales increased. The outer scale consisted of large $\mathrm{TiO}_{2}$ crystals followed by a mixed oxide scale. Furthermore, it is presumed from EDS analysis that this layer consisted predominantly of $\mathrm{TiO}_{2}$ and minor amounts of $\mathrm{Al}_{2} \mathrm{O}_{3}$. Pores and voids were observed within this oxide layer. The oxide next to the substrate was Mo-rich $\mathrm{Ti}_{3} \mathrm{Al}$ layer with bright contrast under SEM. After $350 \mathrm{~h}$ of oxidation, in addition to the thickening of the oxide scale, it was also observed that some microscopic cracks were seen to have formed within the oxide layer as shown in Fig. 8(c); these originated from either a residual stress build-up due to the thick scale or inherent poor cohesion between the scale and the substrate.

In addition to the effect of reducing the thickness of oxide, Y-addition also resulted in the formation of a transitional Yrich subscale between the substrate and the Mo-rich $\mathrm{Ti}_{3} \mathrm{Al}$ scale. Five different chemical compositions were identified for the oxide scales formed in the specimen containing 0.6 at $\% \mathrm{Y}$; the corresponding cross-sectional micrograph and the result of EDS analysis of these are presented in Fig. 9 and Table 3, respectively. Starting from the substrate, the oxides consisted of Y-rich oxide (I)/Mo-rich $\mathrm{Ti}_{3} \mathrm{Al}$ (II)/Mixed scale (III)/Al-rich mixed scale (IV) $/ \mathrm{TiO}_{2}$ (V). As evidenced by elemental distribution maps and line analysis by SEM-EPMA in Fig. 10 and Fig. 11, respectively, there was a transitional 

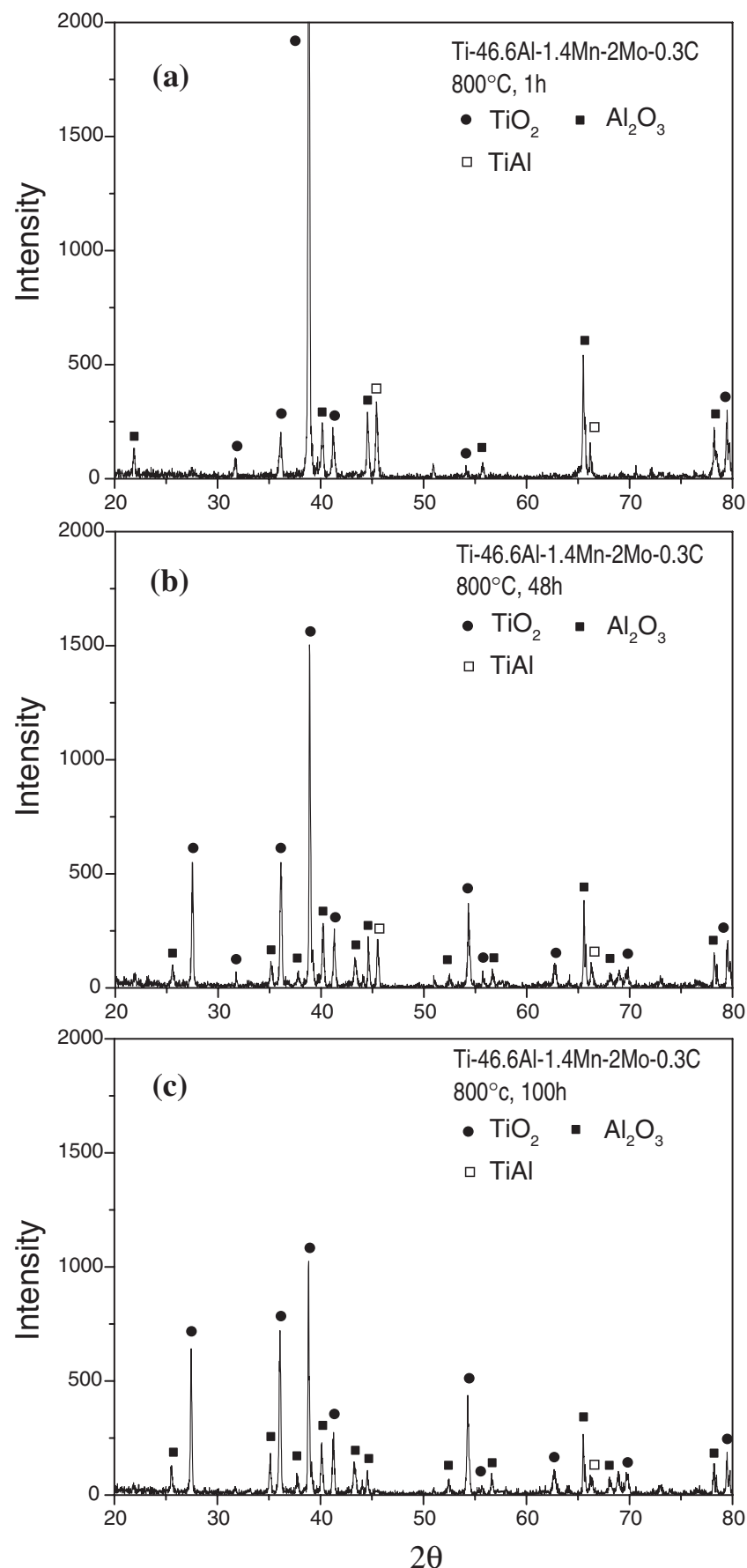

Fig. $5 \mathrm{XRD}$ diffraction spectra (at $1^{\circ}$ angle of incidence) of the oxide scales formed in Ti-46.6Al-1.4Mn-2Mo-0.3C alloy after isothermal exposure at $800^{\circ} \mathrm{C}$ for: (a) $1 \mathrm{~h}$, (b) $48 \mathrm{~h}$ and (c) $100 \mathrm{~h}$.

oxide layer in the $\mathrm{Y}$-enriched innermost region of the $\mathrm{Y}$ containing alloy. The Y-content in this layer was about 1.42 mass\% whereas that in the other layers was below the detection limit. The chemical composition of Mo-rich $\mathrm{Ti}_{3} \mathrm{Al}-$ containing layer was identical to that formed in the $\mathrm{Y}$-free alloy; the existence of the outermost $\mathrm{TiO}_{2}$ layer is also common to both alloys. However, there was a significant difference in the microstructure of the intermediate layer in that a gradual transition occurred from $\mathrm{TiO}_{2}$ to the Mo-rich $\mathrm{Ti}_{3} \mathrm{Al}$ layer in the Y-containing alloy. The transition involved a mixture of Al-rich oxide in the outer layer immediately underneath $\mathrm{TiO}_{2}$ crystals followed by another mixed oxide
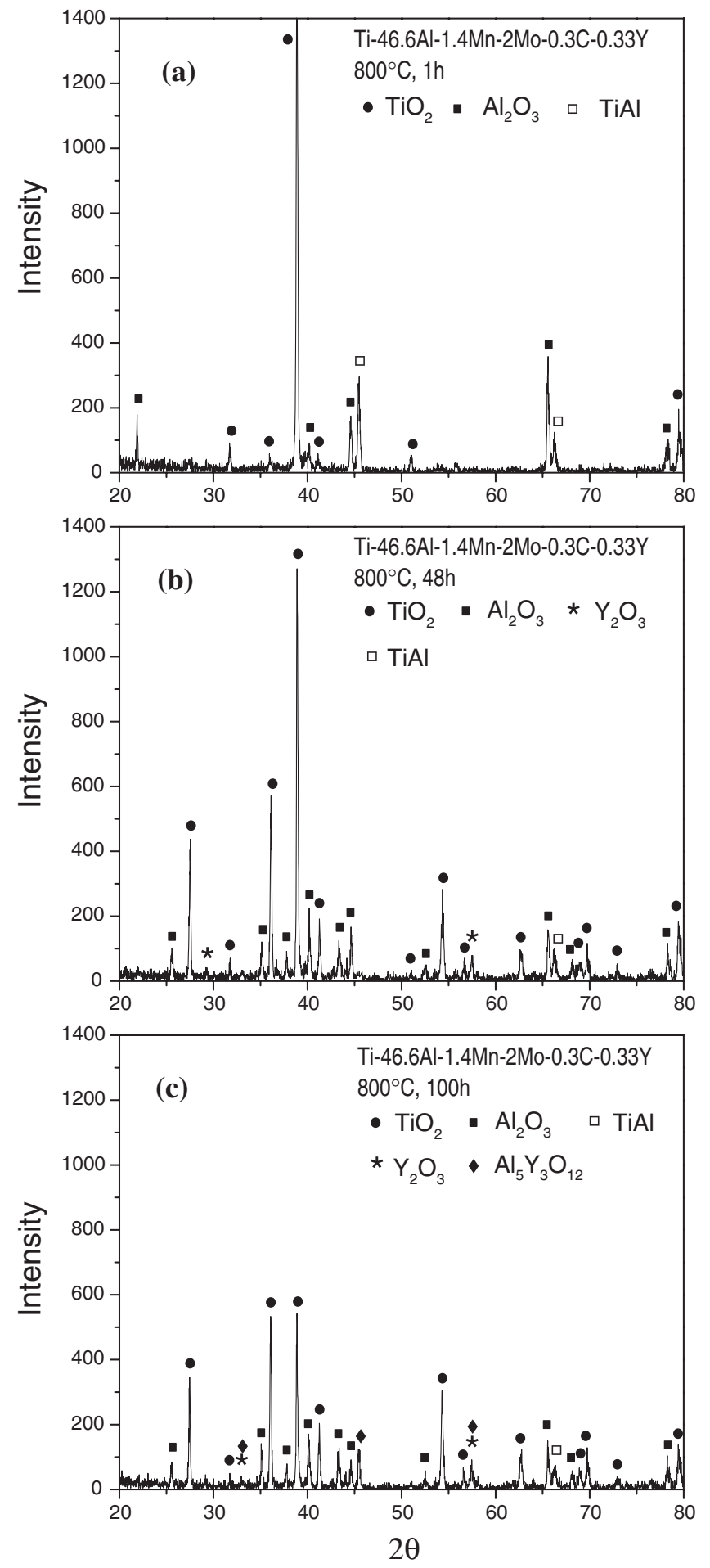

Fig. 6 XRD diffraction spectra (at $1^{\circ}$ angle of incidence) of the oxide scales formed in Ti-46.6Al-1.4Mn-2Mo-0.3C-0.33Y alloy after isothermal exposure at $800^{\circ} \mathrm{C}$ for: (a) $1 \mathrm{~h}$, (b) $48 \mathrm{~h}$ and (c) $100 \mathrm{~h}$.

layer. The distribution of alloying elements in the crosssectional structure in Fig. 11 shows that a peak in the Alcontent is contrasted by a decrease in Ti-content in the fourth layer of the oxide due to the formation of $\alpha-\mathrm{Al}_{2} \mathrm{O}_{3}$. Therefore, there are two additional layers, Y-rich subscale and Al-rich mixed scale, in the Y-containing alloys although the whole scale is quite thin compared to that formed in the Y-free or Y-lean alloys. 

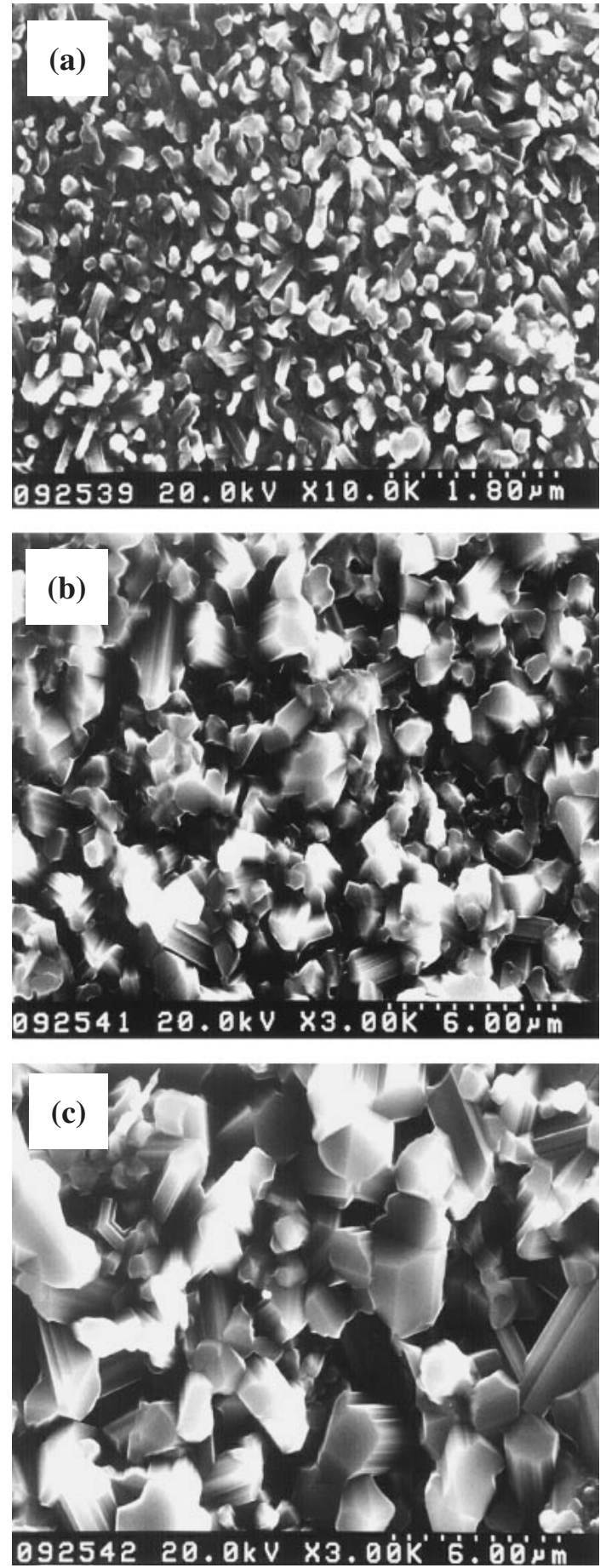

Fig. 7 SEM micrographs of the surface morphology of Ti-46.6Al-1.4Mn$2 \mathrm{Mo}-0.3 \mathrm{C}-0.6 \mathrm{Y}$ alloy after isothermal exposure at $800^{\circ} \mathrm{C}$ for: (a) $1 \mathrm{~h}$, (b) $48 \mathrm{~h}$ and (c) $100 \mathrm{~h}$.

\section{Discussion}

From the present study it is clear that Y-addition improves the oxidation resistance of EPM TiAl-based alloys. Similar studies were reported by several researchers in various alloy systems which support this conclusion. ${ }^{21-25)}$ In most cases, Yadditions reduce the weight gain during oxidation and decrease the parabolic rate constant. Zhang et al. ${ }^{21)}$ studied the oxidation resistance of a $\mathrm{H} 13$ steel implanted with yttrium or yttrium plus carbon, and concluded that yttrium provided a
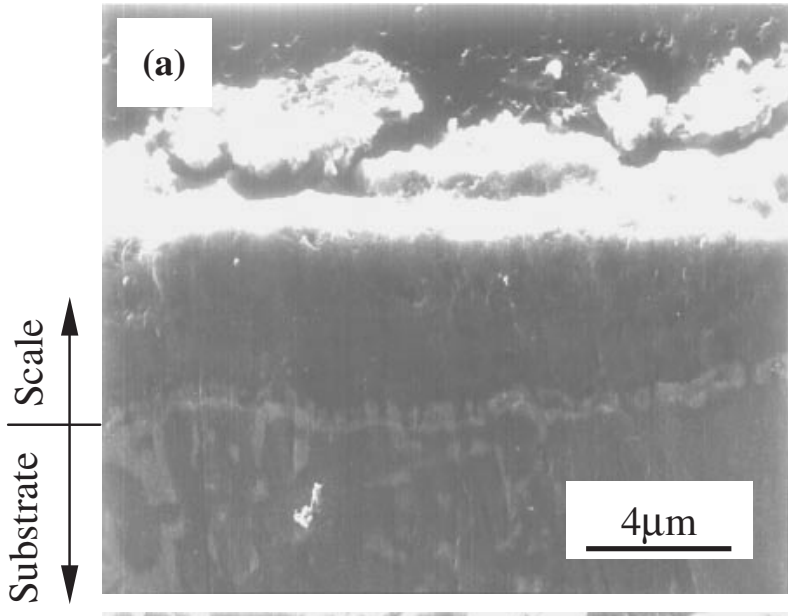

(b)
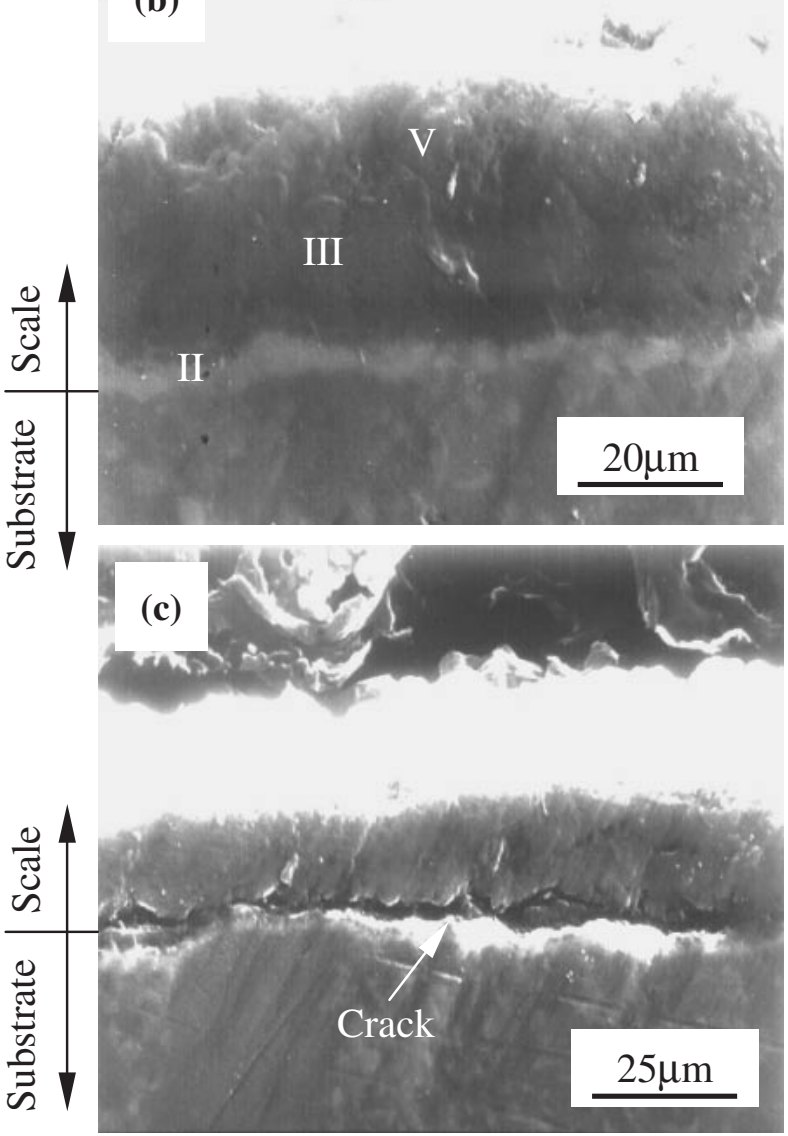

Fig. 8 Cross-sectional SEM micrographs of Ti-46.6Al-1.4Mn-2Mo-0.3C alloy after isothermal exposure in air at $800^{\circ} \mathrm{C}$ for: (a) $48 \mathrm{~h}$, (b) and (c) 350 h. Note: II-Mo-rich layer, III-Mixed layer, V-TiO 2 crystals.

barrier layer for hindering the oxygen diffusion along dislocations or grain boundaries during thermal oxidation. Tsai et $a l .{ }^{22)}$ found that yttrium atoms segregated along grain boundaries and hindered both anionic and cationic intergranular diffusion in $\mathrm{Ni}-30 \mathrm{Cr}$ alloy. $\mathrm{In}_{3} \mathrm{~N}_{3} \mathrm{Al}$-based alloys with yttrium additions, Han et al. ${ }^{25)}$ investigated the mechanism of improvement of high temperature isothermal oxidation resistance and indicated that this resistance of the alloy was substantially improved by the proper amount of yttrium. They demonstrated that the beneficial effects of yttrium on 
Table 3 Comparison of chemical compositions on the oxides of Y-free and 0.6 at $\%$ Y-add alloys after isothermal exposure in air at $800^{\circ} \mathrm{C}$ for $350 \mathrm{~h}$

\begin{tabular}{|c|c|c|c|c|c|c|c|c|}
\hline \multirow{2}{*}{ Alloy } & \multirow{2}{*}{ Layer } & \multicolumn{7}{|c|}{ Elements (mass \%) } \\
\hline & & $\mathrm{Ti}$ & $\mathrm{Al}$ & $\mathrm{Mn}$ & Mo & $\mathrm{Y}$ & $\mathrm{O}$ & $\mathrm{C}$ \\
\hline \multirow{4}{*}{ Y-free } & Substrate & 64.19 & 25.68 & 2.14 & 7.02 & - & 0.18 & 0.79 \\
\hline & II Mo-rich $\mathrm{Ti}_{3} \mathrm{Al}$ & 57.73 & 17.09 & 1.61 & 18.92 & - & 4.63 & 0.02 \\
\hline & III Mixed scale & 56.76 & 29.24 & 0.15 & 3.73 & - & 10.06 & 0.09 \\
\hline & $\mathrm{V} \mathrm{TiO}_{2}$ crystals & 58.15 & 9.00 & 2.29 & 0.22 & - & 30.29 & 0.05 \\
\hline \multirow{5}{*}{$\begin{array}{l}0.6 \text { at } \% \mathrm{Y}- \\
\text { added }\end{array}$} & I Y-rich & 63.21 & 27.79 & 1.96 & 5.06 & 1.42 & 0.55 & 0.01 \\
\hline & II Mo-rich $\mathrm{Ti}_{3} \mathrm{Al}$ & 58.19 & 24.13 & 3.88 & 11.43 & - & 2.35 & 0.02 \\
\hline & III Mixed scale & 51.69 & 21.53 & 0.16 & 2.76 & - & 23.69 & 0.17 \\
\hline & IV Al-rich mixed scale & 44.66 & 41.61 & 1.07 & 0.21 & - & 12.39 & 0.06 \\
\hline & $\mathrm{V} \mathrm{TiO} 2$ crystals & 52.48 & 18.61 & 1.13 & 0.20 & - & 27.51 & 0.07 \\
\hline
\end{tabular}
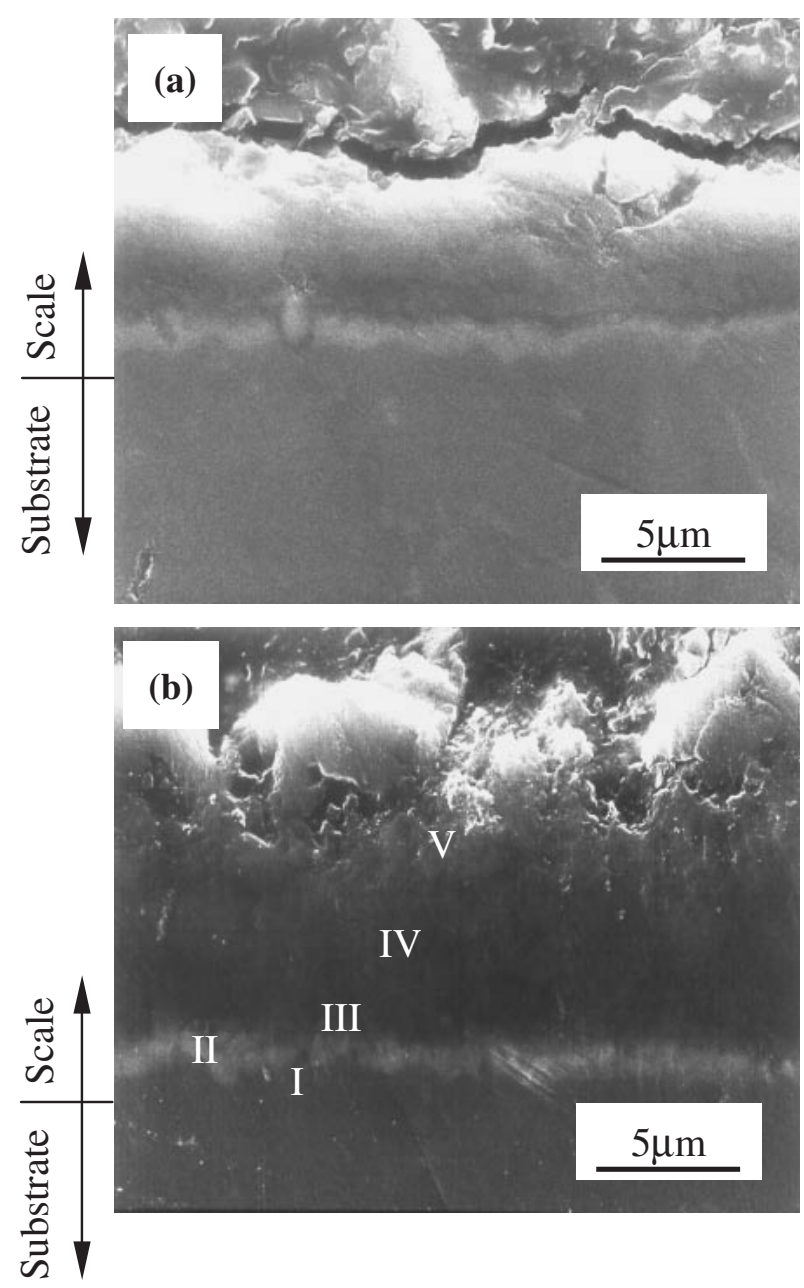

Fig. 9 Cross-sectional SEM micrographs of Ti-46.6Al-1.4Mn-2Mo-0.3C$0.6 \mathrm{Y}$ alloy after isothermal exposure in air at $800^{\circ} \mathrm{C}$ for: (a) $48 \mathrm{~h}$ and (b) 350 h. Note: I-Y-rich layer, II-Mo-rich $\mathrm{Ti}_{3} \mathrm{Al}$ layer, III-Mixed layer, IVAl-rich mixed layer, $\mathrm{V}-\mathrm{TiO}_{2}$ crystals.

high temperature oxidation resistance included: (a) inhibiting the cationic transportation and decreasing the depth of the diffusion layer, (b) promoting the selective oxidation of aluminum and (c) promoting the formation of a fine and closely-packed oxide grain structure. In the present case, the improvement of the oxidation resistance through Y-modification can surmise the effect of yttrium on the microstructure of the oxide scale, i.e., the formation of a transitional Y-rich layer and the increase in the amount of $\alpha-\mathrm{Al}_{2} \mathrm{O}_{3}$ in outer oxides layer.

The alloys with Y-additions showed smaller mass gain and smaller parabolic rate constant. The XRD diffraction spectra showed that in 0.33 at $\%$ Y-added alloy (Fig. 4(c)) and 0.6 at $\%$ Y-added alloy (Fig. 4(d)) exposed at $800^{\circ} \mathrm{C}$ for $350 \mathrm{~h}$, thin oxide scales composed of a mixture of $\mathrm{TiO}_{2}, \alpha-$ $\mathrm{Al}_{2} \mathrm{O}_{3}$, and subscales $\mathrm{Y}_{2} \mathrm{O}_{3}$ and $\mathrm{Al}_{5} \mathrm{Y}_{3} \mathrm{O}_{12}$ were formed. However, in the case of the $\mathrm{Y}$-free alloy, the surface oxides contain only a mixture of $\mathrm{TiO}_{2}$ and $\alpha-\mathrm{Al}_{2} \mathrm{O}_{3}$ (Fig. 4(a)) even after long exposure. In Y-containing alloys, however, the chemical composition of the oxide was modified at $800^{\circ} \mathrm{C}$ for an extended period. Especially for the 0.6 at $\%$ Y-added alloy, both yttrium and internal oxides existed due to intrinsic oxygen and excess yttrium in the sample (Fig. 2(b)). During the exposure at high temperature yttrium reacted with internal and external oxygen and formed the $\mathrm{Y}_{2} \mathrm{O}_{3}$ until the presence of the (Y, Al)O-type subscales. ${ }^{20)}$

In the second stage, oxidation curves of all TiAl-based alloys obeyed the parabolic rate law that was represented by the equation of $(\Delta M)^{2}=K_{\mathrm{p}} t$, where $\Delta M, K_{\mathrm{p}}$ and $\mathrm{t}$ are mass gain, parabolic rate constant and time, respectively. This process was controlled by cation and oxygen transport through the scale. In the present EPM TiAl alloys, two specific sources of oxygen, namely, oxygen inside the intermetallic compound and oxygen in the environment should be considered during the isothermal oxidation at high temperature. Because of the limited solubility of yttrium in TiAl and the strong affinity of yttrium to oxygen, the supersaturated oxygen atoms form $\mathrm{Y}_{2} \mathrm{O}_{3}$ (Fig. 1(b)), and thereby the oxygen-scavenging effect of yttrium is realized. Because $\mathrm{Y}_{2} \mathrm{O}_{3}$ is stable up to $2009^{\circ} \mathrm{C}$ in $\mathrm{TiAl},{ }^{30)}$ the oxide is not decomposed during exposure at $800^{\circ} \mathrm{C}$ in air. The quantity of $\mathrm{Y}_{2} \mathrm{O}_{3}$ formed inside $\mathrm{TiAl}$ is proportional to the quantity of yttrium added. In fact the quantity of $\mathrm{Y}_{2} \mathrm{O}_{3}$ increased in the high-Y alloy with exposure time at $800^{\circ} \mathrm{C}$. The content of oxygen analyzed by EDS (see Table 3) indicates the average in the oxides and the matrix in solid solution, although quantitative distinction is difficult at 

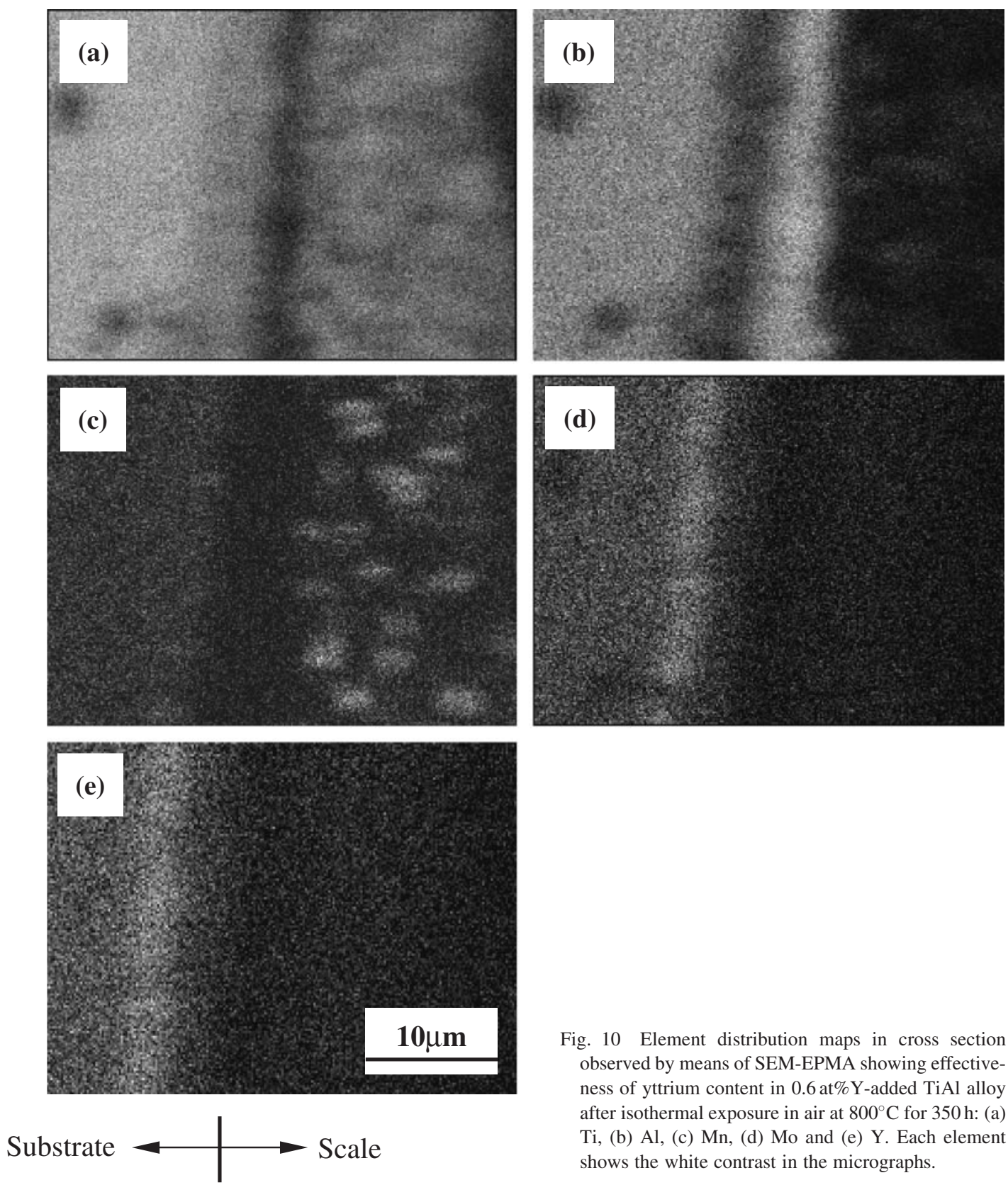

Fig. 10 Element distribution maps in cross section observed by means of SEM-EPMA showing effectiveness of yttrium content in 0.6 at $\%$ Y-added TiAl alloy after isothermal exposure in air at $800^{\circ} \mathrm{C}$ for $350 \mathrm{~h}$ : (a) Ti, (b) Al, (c) Mn, (d) Mo and (e) Y. Each element shows the white contrast in the micrographs.

present. In this respect, the improvement in high temperature oxidation behavior by yttrium addition can be explained by Wagner's classical theory: ${ }^{32)}$ the oxidation resistance of the alloy is in reverse proportion to the oxygen solubility. According to this interpretation, yttrium enhances the oxidation resistance by lowering the oxygen solubility in TiAl through the formation of $\mathrm{Y}_{2} \mathrm{O}_{3}$ phase. The results presented in Fig. 3 indicate that this effect is proportional to the yttrium content, not exceed 0.6 at $\%$. Consequently, the decrease of oxygen concentration inside TiAl by addition of yttrium is undoubtedly useful for the oxidation resistance although the degree of the effect is limited. However, the most beneficial effect of yttrium lies in upgrading the chemical and morphological characteristics of the scale.

A schematic illustration of the oxide scale in Y-free and 0.6 at\% Y-containing alloys is shown in Figs. 12(a) and (b), respectively, in which the scale structure and the role of yttrium in the Y-containing alloy are explained compared with those in Y-free TiAl. The unique presence of an intermediate layer is illustrated, the thin Y-rich subscale layer and Al-rich mixed layer. Y-addition induces formation of the subscale layer that is significantly more resistant to atmospheric oxygen than $\mathrm{TiO}_{2}$ is. As shown in the XRD phase analysis of the oxide scale, the Y-rich layer contained (Y, Al)O-type oxides except for other oxides. According to the equilibrium diagram, ${ }^{33}$ (Y, $\left.\mathrm{Al}\right) \mathrm{O}$-type oxides form if aluminum reacts with oxygen in the $\mathrm{Y}_{2} \mathrm{O}_{3}$ scale. The reaction of alumina and yttria is as follows: ${ }^{23)}$

$$
\begin{aligned}
\mathrm{Y}_{2} \mathrm{O}_{3}+\mathrm{Al}_{2} \mathrm{O}_{3} & =2 \mathrm{YAlO}_{3} \\
3 \mathrm{YAlO}_{3}+\mathrm{Al}_{2} \mathrm{O}_{3} & =\mathrm{Al}_{5} \mathrm{Y}_{3} \mathrm{O}_{12}
\end{aligned}
$$

Therefore, $\alpha-\mathrm{Al}_{2} \mathrm{O}_{3}$ and $\mathrm{Y}_{2} \mathrm{O}_{3}$ are precursors for the formation of the $\mathrm{Al}_{5} \mathrm{Y}_{3} \mathrm{O}_{12}$. The latter phase is better for oxidation resistance than $\mathrm{TiO}_{2}$ although it is also non- 


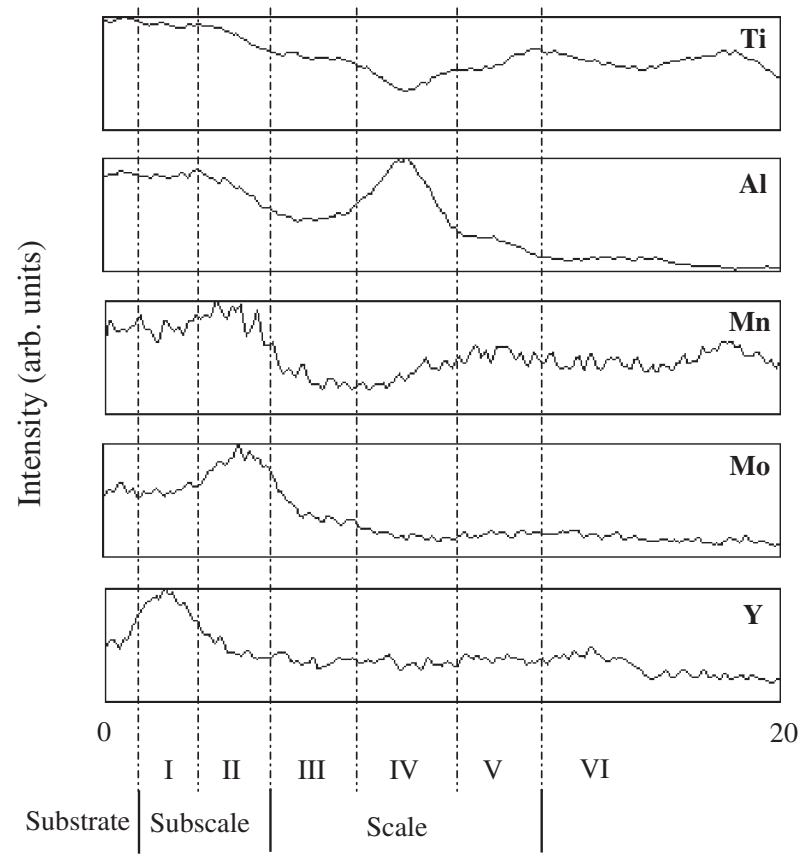

Distance, $d / \mu \mathrm{m}$

Fig. 11 Distributions of each element found by EPMA of the cross-section of the oxide scale on the 0.6 at $\% \mathrm{Y}$-added alloy at $800^{\circ} \mathrm{C}$ for $350 \mathrm{~h}$. Note: IY-rich layer, II-Ti ${ }_{3} \mathrm{Al}$ layer with Mo-rich, III-Mixed layer, IV-Al-rich mixed layer, $\mathrm{V}-\mathrm{TiO}_{2}$ crystals layer, VI-plastic grinding mounts.

protective. In the Y-containing alloys, because of the lower solubility of yttrium in $\mathrm{Al}_{2} \mathrm{O}_{3},{ }^{23)}$ yttrium was apt to form the (Y, Al)O-type oxides in the Y-rich area in the transitional layer. Particularly, the addition of yttrium promoted the formation of $\mathrm{Al}_{2} \mathrm{O}_{3}$, which evidenced by a considerable amount of $\mathrm{Al}_{2} \mathrm{O}_{3}$ in the outer scale and the presence of (Y, $\mathrm{Al}) \mathrm{O}$-type oxides because the formation of the latter needed a large supply of $\mathrm{Al}_{2} \mathrm{O}_{3}$. In the $\mathrm{Y}$-free alloy, however, the lack of protective Al-rich layer in the scale resulted in a fast oxidation with a thick scale, see Table 2 and Fig. 8. Therefore, the Y-rich subscale and Al-rich mixed layer may delay the diffusion of $\mathrm{Ti}$ and oxygen transport from the atmosphere, resulting in the improvement of TiAl-based alloys.

The improvement of cracking resistance with yttrium additions in TiAl-based alloys was closely related to the thinness of the scale. In this case, the thermal stress arising from the difference in the thermal expansion coefficient between the matrix and the oxide during the oxidation was easily removed. As for the Y-free alloy, the thickening of the scale resulted in scale spallation (Fig. 8(c)). In contrast, absence of any interface crack in the Y-containing alloy, see Fig. 9, manifests the effect of yttrium on resisting cracking and spalling of the scale.

\section{Conclusions}

The effect of Y-addition on the high temperature oxidation behavior of EPM TiAl-Mn-Mo-C alloys was examined and the following conclusions were drawn:

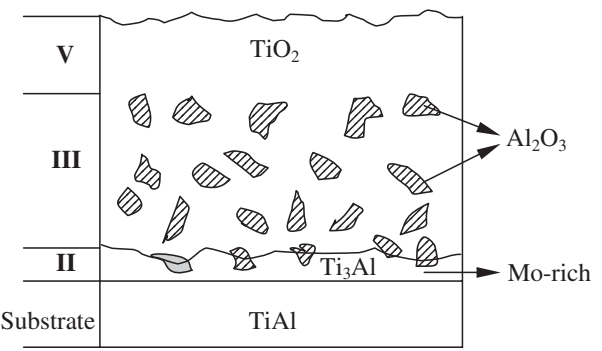

(a)

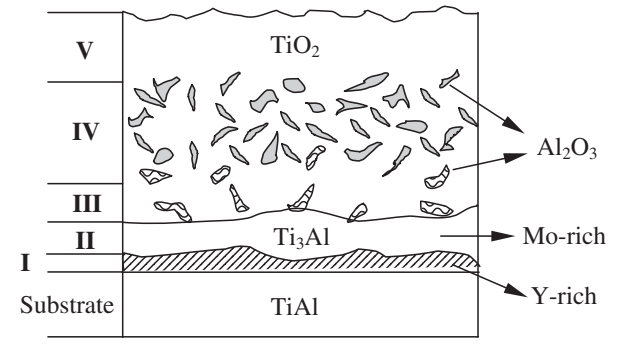

(b)

Fig. 12 Schematic of the cross-sectional microstructure of the oxide formed in (a) Y-free alloy and (b) 0.6 at\% Y-added alloy after isothermal exposure in air at $800^{\circ} \mathrm{C}$ for $350 \mathrm{~h}$. I-Y-rich layer, $\mathrm{II}_{-} \mathrm{Ti}_{3} \mathrm{Al}$ layer enriched with Mo, III-Mixed layer, IV-Al-rich mixed layer, $\mathrm{V}-\mathrm{TiO}_{2}$ crystals layer.

(1) Y-additions remarkably improved the oxidation resistance of EPM TiAl-1.4Mn- 2Mo-0.3C alloys exposed at $800^{\circ} \mathrm{C}$ for $350 \mathrm{~h}$. With increasing yttrium content from 0.1 at $\%$ to 0.6 at $\%$, the mass gain and scale thickness as well as the parabolic rate constant of the experimental alloys decreased in sequence.

(2) Due to the oxygen-scavenging effect of yttrium by the formation of $\mathrm{Y}_{2} \mathrm{O}_{3}$, the concentration of internal oxygen in the matrix of TiAl introduced during EPM processing was decreased, especially for the 0.6 at $\% \mathrm{Y}-$ added alloy, and oxidation resistance of the alloys was improved.

(3) The structures of the scales were modified by Yadditions. A transitional Y-rich subscale adjacent to the substrate and a mixed scale with a considerable amount of $\alpha-\mathrm{Al}_{2} \mathrm{O}_{3}$ oxides in the intermediate layer underneath $\mathrm{TiO}_{2}$ crystals were formed in the Y-added alloys. Mo was enriched in the $\mathrm{Ti}_{3} \mathrm{Al}$ oxide layer. The formation of the (Y, Al)O-type oxides was correlated with improving the oxidation resistance of EPM TiAl-Mn-Mo-C alloys.

\section{Acknowledgments}

This research was performed under the auspices of KISTEP through the 2002 National Research Laboratory Program of the Korean Ministry of Science and Technology. This work was partly supported by a Grant-in-Aid for Scientific Research and Development from the Ministry of Education, Culture, Sports, Science and Technology of Japan. Dr. Wu would like to thank the Japan Society for the Promotion of Science (JSPS) for a postdoctoral fellowship for Foreign Researchers. 


\section{REFERENCES}

1) I. C. I. Okafor and R. G. Reddy: JOM 47 (1999) 35-39.

2) S. Taniguchi: Bulletin of Japan Inst. Metals 31 (1992) 497-504.

3) H. Anada and Y. Shida: Mater. Trans. JIM. 36 (1995) 533-539.

4) B. G. Kim, G. M. Kim and C. J. Kim: Scr. Metall. Mater. 33 (1995) 1117-1125.

5) M. Yoshihara and K. Miura: Intermetallics. 3 (1995) 357-363.

6) B. Y. Huang, Y. H. He and J. N. Wang: Intermetallics. 7 (1999) 881888.

7) T. Narita, T. Izumi, M. Yatagai and T. Yoshioka: Intermetallics. 8 (2000) 371-379.

8) H. R. Jiang, M. Hirohasi, Y. Lu and H. Imanari: Scr. Mater. 46 (2002) 639-643.

9) H. N. Lee, Z. M. Park, M. H. Oh, K. Y. Kim and D. M. Wee: Scr. Mater. 41 (1999) 1073-1078.

10) Z. Tang, L. Niewolak, V. Shemet, L. Singheiser, W. J. Quadakkers, F Wang, W. Wu and A. Gil: Mater. Sci. Eng. A. 328 (2002) 297-301.

11) M. F. Stroosnijder, N. Zheng, W. J. Quadakkers and H. J. Schmutzler: Surf. Coat. Technol. 83 (1996) 212-217.

12) V. A. C. Haanappel and M. F. Stroosnijder: Surf. Coat. Technol. 105 (1998) 147-154.

13) K. Maki, M. Shioda and M. Sayashi: Mater. Sci. Eng. A. 153 (1992) 591-596.

14) S. Becker, A. Rahmel, M. Schorr and M. Schütze M: Oxid Met. 38 (1992) 425-464.

15) N. Zheng, W. J. Quadakkers, A. Gil and H. Nickel: Oxid Met. 44 (1995) 477-499.

16) Y. Shida and H. Anada: Oxid Met. 45 (1996) 197-219.

17) M. P. Brady, J. L. Smialek, D. L. Humphrey and J. Smith: Acta Mater.
45 (1997) 2371-2382.

18) V. A. C. Haanappel, H. Clemens and M. F. Stroosnijder: Intermetallics. 10 (2002) 293-305.

19) Y. Wu and S. K. Hwang: Acta Mater. 50 (2002) 1479-1493.

20) Y. Wu, S. K. Hwang, S. W. Nam and N. J. Kim: Scr. Mater. 48 (2003) 1655-1660.

21) T. H. Zhang, J. D. Xie, C. Z. Ji, J. Chen, H. Xu, J. Li, G. R. Sun, H. X Zhang: Surf. Coat. Technol. 72 (1995) 93-98.

22) S. C. Tsai, A. M. Huntz, C. Dolin: Oxid Met. 43 (1996) 581-596.

23) H. G. Jung and K. Y. Kim: Oxid Met. 49 (1998) 403-430.

24) G. Calvarin, A. M. Huntz, A. Hugot Le Goff, S. Joiret and M. C. Bernard: Scr. Mater. 38 (1998) 1649-1658.

25) Y. F. Han, C. B. Xiao: Intermetallics. 8 (2000) 681-691.

26) T. K. Lee, E. I. Mosunov, S. K. Hwang: Mater. Sci. Eng. A. 239 (1997) 540-545.

27) H. S. Park, S. K. Hwang, C. M. Lee, Y. C. Yoo, S. W. Nam and N. J. Kim: Metall. Trans. A. 32 (2001) 251-259.

28) Y. Wu and S. K. Hwang: Metals and Materials. 7 (2001) 191-199.

29) Y. Wu, Y. W. Park, H. S. Park and S. K. Hwang: Mater. Sci. Eng. A. 347 (2003) 171-179.

30) Y. Kobayashi and F. Tsukihashi: Metall. Trans B. 29 (1998) 10371042.

31) A. Menand, A. Huguet and A. Nérac-partaix: Acta Mater. 44 (1996) 4729-4737.

32) M. Yoshihara and Y. W. Kim: Gamma titanium aluminides 1999, ed. by Y. W. Kim, D. M. Dimiduk, M. H. Loretto, (The Minerals, Metals \& Materials Society, Warrendale, PA, 1999) pp. 753-760.

33) H. A. Topopob, I. A. Bondar, F. Ya. Galakhow, Kh. S. Nikogovyan and N. V. Vinogradova: Izv. Akad. Nauk SSSR. Ser. him. 7 (1964) 11581164. 